\title{
PENGARUH TRUST IN A BRANDTERHADAP BRAND LOYALTY PADA KONSUMEN AIR MINUM AQUA DI KOTA AMBON
}

\author{
H a m k a \\ Staf Pengajar FAPERTA UMMU-Ternate, $\boldsymbol{e}$-mail:-
}

\begin{abstract}
ABSTRAK
Penelitian ini bertujuan untuk mempelajari secara empirik pengaruh dari variabel trust in a brand yang meliputi brand characteristic, company characteristic, dan consumer - brand characteristic terhadap brand loyalty. Merek yang diteliti adalah merek air minum Aqua, yang respondennya diambil dari para pengguna air minum Aqua yang ada di Kota Ambon. Hasil penelitian ini menunjukkan bahwa secara bersama-sama dan parsial variabel trust in a brand berpengaruh signifikan terhadap brand loyalty. Pengaruh variabel trust in a brand terhadap brand loyalty adalah sebesar 0,971 dengan tingkat signifikan sebesar 0,000. Sebaliknya, secara parsial pengaruh variabel trust in a brand adalah sebagai berikut. Pertama brand characteristic berpengaruh signifikan terhadap brand loyalty dengan koefisien beta sebesar 0,668 dengan tingkat signifikan sebesar 0,000, di mana brand characteristic berpengaruh dominan terhadap brand loyalty. Company characteristic mempunyai pengaruh signifikan terhadap brand loyalty dengan koefisien beta sebesar 0,224 dengan tingkat signifikan sebesar 0,000. Consumer brand characteristic juga berpengaruh signifikan terhadap brand loyalty dengan koefisien beta sebesar 0,165 dengan tingkat signifikan sebesar 0,000.

Dalam upaya meningkatkan loyalitas merek, pihak perusahaan harus senantiasa meningkatkan dan mempertahankan kepercayaan pelanggan terhadap perusahaan. Brand characteristik sebagai salah satu variabel yang berpengaruh dominan harus tetap dapat dikendalikan secara langsung oleh perusahaan.
\end{abstract}

Kata Kunci: Trust in a brand, brand loyalty

\section{PENDAHULUAN}

\subsection{Latar Belakang}

Dalam kondisi persaingan yang semakin ketat, setiap perusahaan harus mampu bertahan hidup, bahkan harus dapat terus berkembang. Salah satu hal penting yang perlu dilakukan dan diperhatikan oleh setiap perusahaan adalah mempertahankan pelanggan yang telah ada, terus menggarap pelanggan-pelanggan potensial baru agar jangan sampai pelanggan meninggalkan perusahaan menjadi pelanggan perusahaan lain. Dengan kata lain perusahaan harus mampu mempertahankan loyalitas pelanggan.

Loyalitas pelanggan terhadap merek produk merupakan konsep yang sangat penting khususnya pada kondisi tingkat persaingan yang sangat ketat dengan pertumbuhan yang rendah. Pada kondisi demikian loyalitas pada merek sangat dibutuhkan agar perusahaan dapat bertahan hidup. Di samping itu, upaya mempertahankan loyalitas merek ini merupakan upaya strategis yang lebih efektif dibandingkan dengan upaya menarik pelanggan baru.

Persoalan merek menjadi salah satu persoalan yang harus dipantau secara terusmenerus oleh setiap perusahaan. Merek-merek yang kuat, teruji, dan bernilai tinggi terbukti tidak hanya sukses mengalahkan hitungan-hitungan rasional, tetapi juga canggih mengolah sisi - sisi emosional konsumen. Merek bisa memiliki nilai tinggi karena ada brand building activity yang bukan sekadar berdasarkan komunikasi, tetapi merupakan segala macam usaha lain untuk memperkuat merek tersebut.

Dari komunikasi, merek bisa menjanjikan sesuatu, bahkan lebih dari janji, merek juga mensinyalkan sesuatu (brand signaling). Merek akan mempunyai reputasi jika ia memiliki kualitas dan karisma. Agar memiliki karisma, merek harus mempunyai aura, harus konsisten, kualitasnya harus dijaga dari waktu ke waktu, selain tentunya juga harus mempunyai kredibilitas. 
Agar tampil menjadi yang terbaik, tentu suatu merek harus terlihat seksi di pasar hingga mampu membuat konsumen tertarik membelinya. Agar terlihat seksi, merek tersebut harus memiliki costumer value jauh di atas merekmerek yang lain. Selain itu, harus mampu meningkatkan keterlibatan emosi pelanggan sehingga pelanggan mempunyai ikatan dan keyakinan terhadap merek tersebut.

Sebagai salah satu produsen air minum terbesar dan pertama di Indonesia, tentu Aqua tidak menghendaki para pelanggannya beralih ke produk lain. Oleh sebab itu, tuntutan untuk selalu menjadi yang terbaik harus menjadi komitmen organisasi agar para pengguna air minum masih tetap setia untuk selalu mengkonsumsi air minum Aqua. Kesetiaan pelanggan tidak dapat begitu saja diraih, tetapi memerlukan proses panjang untuk meyakinkan bahwa Aqua merupakan air minum terbaik.

\subsection{Rumusan Masalah}

Dari latar belakang masalah yang telah diuraikan dapat dirumuskan permasalahan sebagai berikut. (1) Apakah variabel brand characteristic, company characteristic, dan consumer-brand characteristic secara bersamasama berpengaruh signifikan terhadap brand loyalty pada konsumen air minum Aqua ? (2) Apakah variabel brand characteristic, company characteristic, dan consumer-brand characteristic secara parsial berpengaruh signijikan terhadap brand loyalty pada konsumen air minum Aqua serta variabel mana yang berpengaruh dominan?

\subsection{Tujuan Penelitian}

Sesuai dengan permasalahan yang telah dirumuskan, tujuan penelitian yang hendak dicapai adalah sebagai berikut:

(1) Untuk mengetahui pengaruh secara bersamasama variabel brand characteristic, company characteristic, dan consumer - brand characteristic terhadap brand loyalty pada konsumen air minum Aqua.

(2) Untuk mengetahui pengaruh secara parsial variabel brand characteristic, company characteristic, dan consumer

- brand characteristic terhadap brand loyalty pada konsumen air minum Aqua serta variabel yang dominan berpengaruh.

\section{METODE PENELITIAN}

\subsection{Hipotesis}

Hipotesis yang diajukan sebagai jawaban sementara terhadap permasalahan yang diajukan dalam penelitian ini adalah sebagai berikut.

1. Variabel brand characteristic, company characteristic dan consumer-brand characteristic secara bersama-sama berpengaruh signifikan terhadap brand loyalty.

2. Secara parsial variabel brand characteristic, company characteristic, dan consumer brand characteristic berpengaruh signifikan terhadap brand loyalty dan yang mempunyai pengaruh dominan adalah variabel brand characteristic.

\subsection{Identifikasi Variabel}

Variabel-variabel dalam penelitian ini meliputi tiga variabel independen (X), yaitu brand characteristic $\left(\mathrm{X}_{1}\right), \quad$ company characteristic (X2), dan consumer - brand characteristic (X3). Sebaliknya, variabel dependen (Y) hanya satu yaitu brand loyalty. Variabel-variabel serta indikator penelitian ini dapat dilihat pada Tabel 1.

\subsection{Penentuan Populasi dan Sampel}

Teknik pengambilan sampel dilakukan dengan Quota Accidental Sampling, yaitu dengan penetapan jumlah anggota sampel secara quota atau jumlah terhadap konsumen yang mudah ditemui pada saat survei dilakukan. Sebelum survei dilakukan calon responden diberikan penjelasan tentang indikator penelitian yang berupa pernyataan sehingga hasil jawaban responden yang didapat dari sampel nantinya mewakili sifat- sifat populasi di mana sampel tersebut ditarik. Para pengguna air mineral sebagai calon responden ditemui di lokasi tersebut dan ditawari kesediaannya untuk menjadi responden.

Karena adanya keterbatasan waktu, tenaga, dan biaya, batasan jumlah sampel yang diambil dari seluruh populasi adalah sebanyak lima sampai dengan sepuluh kali jumlah indikator dari variabel bebas yang diteliti (Santosa: 2001). Jadi, atas dasar kriteria tersebut diatas dapat ditentukan jumlah sampel minimal yang diambil adalah:

$$
\mathrm{n}=5 \mathrm{xI}=5 \times 19=95
$$

Keterangan:

$\mathrm{n}=$ Ukuran sampel

$\mathrm{I}=$ Jumlah indikator variabel bebas yang diteliti 
Responden yang dijadikan sampel penelitian diperluas menjadi enam kali jumlah indikator variabel bebas menjadi 114 orang responden. Dari 114 orang responden yang digunakan sebagai sampel penelitian dicari responden yang telah berkeluarga, baik laki laki maupun perempuan, baik yang berpendidikan maupun tidak berpendidikan, berstatus pekerja atau tidak bekerja, dan semua responden adalah pengguna air minum merek Aqua.

\subsection{Jenis dan Sumber Data}

Data yang digunakan dalam penelitian ini meliputi dua jenis data, yaitu sebagai berikut.

(1) Data primer merupakan data yang diperoleh dari hasil penyebaran kuesioner kepada warga masyarakat Kota Ambon yang mengkonsumsi air minum Aqua.

(2) Data sekunder, yaitu data yang bersumber dari PT Tirta Investama dan sumber-sumber lain yang telah tersedia sebelumnya berkaitan dengan penelitian.

\subsection{Teknik Pengumpulan Data}

(1) Wawancara

Teknik wawancara digunakan untuk mengumpulkan data dengan melakukan pertanyaan langsung kepada para responden dan pihak yang berkompeten dalam penelitian. Wawancara dilakukan dengan metode angket yang berisi berbagai pertanyaan tentang variabel penelitian.. Data dikumpulkan dengan cara membagikan angket kepada para calon responden khususnya pengguna air minum Aqua pada tempat-tempat penjualan air minum Aqua.

(2) Observasi

Teknik pengumpulan data dengan melakukan pengamatan langsung terhadap objek yang diteliti dalam mengumpulkan informasi penelitian. Observasi dilakukan dengan melihat dokumen-dokumen, arsip-arsip, baik yang berupa laporan maupun catatan yang tersedia pada perusahaan.

\subsection{Uji Validitas dan Reliabilitas}

Validitas adalah suatu ukuran yang menunjukkan tingkat keabsahan dan kevalidan suatu alat ukur atau instrumen penelitian. Validitas menunjukkan sejauh mana suatu alat ukur mampu mengukur apa yang diukur dalam suatu penelitian. Alat pengukur yang absah akan mempunyai validitas yang tinggi. Untuk menguji validitas alat ukur atau instrumen penelitian terlebih dahulu di cari nilai (harga) korelasi dengan mennggunakan rumus korelasi Product Moments Pearson.

Reliabilitas mengarah pada keajegan suatu alat ukur. Tingkat reliabilitas memperhatikan sejauh mana alat ukur dapat diandalkan dan dipercaya sehingga hasil pengukuran tetap konsisten jika dilakukan pengukuran berulangulang terhadap gejala yang sama dengan alat ukur yang sama pula.

\subsection{Teknik Analisis Data}

\subsubsection{Metode Suksesif Interval}

Sebelum melakukan analisis regresi berganda, tahap awal yang dilakukan adalah melakukan pengolahan data dengan mengubah data ordinal menjadi data interval dengan menggunakan metode suksesif interval.

Metode suksesif interval berfungsi untuk mengubah data ordinal menjadi interval. Suatu daftar pertanyaan biasanya menghasilkan data ordinal misalnya dengan skala likert di mana tidak menunjukkan perbandingan antarjawaban secara nyata. Dengan data interval perbandingan antara jawaban yang sebanarnya akan terlihat tajam sehingga selanjutnya dapat diolah untuk memperoleh suatu nilai jawaban responden.

\subsubsection{UjiAsumsi Regresi Berganda}

\section{a. Uji Linieritas}

Linieritas adalah keadaan yang menunjukkan hubungan antara variabel brand loyalty dengan variabel brand charakteristic, company characteristic, dan consumer-brand characteristic bersifat linier (garis lurus) dalam range variabel independen tertentu. Linieritas diuji dengan menggunakan scatter plot (diagram pencar).

b. Uji Normalitas

Tujuan uji normalitas adalah untuk mengetahui apakah distribusi sebuah data mengikuti atau mendekati distribusi normal, yakni distribusi data dengan bentuk lonceng (bell shaped). Data yang baik adalah data yang mempunyai pola seperti distribusi normal, yaitu distribusi data tersebut tidak menceng ke kanan dan ke kiri.

Uji normalitas pada multivariate sebenarnya sangat kompleks karena harus dilakukan pada sebuah variabel secara bersamasama. Namun, uji ini bisa juga dilakukan pada sebuah variabel dengan logika bahwa jika secara individual tiap-tiap variabel memenuhi asumsi normalitas, maka secara bersama-sama (multivariate) variabel-variabel tersebut dianggap memenuhi asumsi normalitas. 
c. Uji Multikolinieritas

Adanya multikolinieritas merupakan pelanggaran dalam asumsi klasik. multikolinieritas maksudnya tidak boleh terjadi hubungan antarvariabel bebas (independent). Untuk mendeteksi gejala multikolinieritas dapat dilakukan dengan menggunakan besaran VIF (Variance Influence Faktor) dan angka toleran. Pedoman suatu model regresi yang bebas multikol apabila mempunyai nilai VIF lebih kecil daripada 10 dan angka tolerance mendekati 1 (Santosa, 2000 : 206).

d. Uji Heteroskedastisitas

Uji heteroskedastisitas bertujuan untuk menguji apakah dalam model regresi terjadi ketidaksamaan variance dan residual satu pengamatan ke pengamatan lain. Jika variance dan residual satu pengamatan ke pengamatan yang lain tetap, maka terjadi homokedastisitas. Model regresi yang baik adalah yang homokedastisitas atau tidak terjadi heteroskedastisitas (Ghozali, 2001 : 69).

Uji heteroskedastisitas dilakukan dengan cara melihat plots antara nilai prediksi (ZPRED) dengan residual (SRESID). Deteksi ada tidaknya pola tertentu pada grafik scarplots antara SRESID dengan ZPRED di mana sumbu $Y$ adalah $\mathrm{Y}$ yang telah diprediksi dan sumbu $\mathrm{X}$ adalah residual (Y prediksi - Y sesungguhnya) yang telah di- studentized (Ghozali, $2001: 69$ ).

e. Uji Autokorelasi

Uji autokorelasi dilakukan untuk mengetahui apakah terjadi korelasi antarvariabel bebas dalam penelitian. Untuk mengetahui ada tidaknya autokorelasi, dapat dilihat dari nilai Durbin - Watson test. Apabila nilai Durbin Watson test mendekati nilai 2, maka dapat dikatakan bahwa tidak terjadi autokorelasi pada variabel bebas.

\subsubsection{Analisis Regresi Berganda}

Model regresi digunakan untuk mengasumsikan bahwa terdapat hubungan linier antara variabel brand loyalty dengan variabel brand characteristic, company characteristic, dan consumer - brand characteristic.

Adapun model persamaan regresi yang dapat diperoleh dalam analisis ini adalah:

$$
\mathrm{Y}=\mathrm{P}_{0}+\mathrm{P}_{1} \mathrm{X}_{1}+\mathrm{P}_{2} \mathrm{X}_{2}+\mathrm{P}_{3} \mathrm{X}_{3}+\mathrm{e}
$$

Keterangan:

$$
\begin{array}{ll}
\mathrm{Y} & =\text { Brand Loyalty } \\
\mathrm{Po} & =\text { Constanta } \\
\mathrm{P}_{1} \mathrm{P}_{2} \mathrm{P}_{3} & =\text { Koefisien Regresi } \\
\mathrm{X}_{1} & =\text { Brand characteristic } \\
\mathrm{X}_{2} & =\text { Company characteristic } \\
\mathrm{X}_{3} & =\text { Consumer-brand characteristic }
\end{array}
$$

Pada dasarnya analisis regresi adalah untuk memperoleh persamaan regresi dengan cara memasukkan perubah satu demi satu sehingga dapat diketahui pengaruh yang paling kuat sampai dengan yang paling lemah.

\section{PENGARUH VARIABLE TRUST IN BRAND TERHADAP BRAND LOYALTY}

\subsection{Gambaran Umum PT Tirta Investama}

Perusahaan air minum Aqua mempunyai sejarah pendirian yang unik, adalah Bapak Tirto Utomo seorang eksportir minyak Pertamina, yang dulu sering menjadi delegasi perminyakan Indonesia untuk mengikuti kongres perminyakan. Pada suatu kongres perminyakan di Jakarta, Bapak Tirto Utomo mendapatkan suatu teguran dari delegasi luar negeri yang mengalami sakit perut (diare). Setelah diselidiki penyebabnya adalah air minum yang kurang sehat.

Bertolak dari pengalaman di atas, Bapak Tirto Utomo mempunyai ide untuk membuat air minum dalam kemasan yang sehat dan aman diminum setiap saat. Setelah melalui berbagai proses, pada tahun 1974 berdirilah PT Golden Missisipi yang memproduksi air minum dalam kemasan dengan merek Aqua.

Seiring dengan semakin membaiknya pemasaran dan banyaknya permintaan akan air minum dalam kemasan Aqua, pada tahun 1984 dibuka cabang perusahaan di Pandaan, Jawa Timur, yaitu PT Tirta Jayamas Unggul. Pada tahun 1987 dibuka lagi anak cabang perusahaan yaitu PT Tirta Dewata Semesta di Banjar Gumasih, Desa Mambal, Abiansemal, Badung, Bali. Pada tahun 1998 PT Tirta Dewata Semesta diganti namanya menjadi PT. Tirta Investama.

\subsection{Aliansi Strategis Aqua - Danone}

Langkah strategis Aqua untuk menghadapi era globalisasi diputuskan dengan menjalin aliansi strategis dengan pemain global yang telah mempunyai reputasi tinggi di bidang air minum dalam kemasan, yaitu grup Danone. Aliansi ini sesuai dengan komitmen Aqua kepada pelanggan untuk memproses produknya dengan menggunakan peralatan canggih dan modern serta didukung oleh tim yang terlatih, berkualitas, dan profesional. Aqua bergabung dengan grup Danone pada 4 September 1998 dan pada awal Januari 2000 melahirkan sebuah kesepakatan $\mathrm{Co}$ branding, yang berarti pada setiap produk Aqua tercantum kedua logo perusahaan. 


\subsection{Uji Validitas dan Reliabilitas}

Data yang diperoleh melalui kuesioner sebelum diolah dan dianalisis dilakukan uji validitas dan reliabilitas kuesioner. Uji validitas dimaksudkan untuk mengetahui sejauh mana suatu pengukuran secara tepat memberikan hasil bila dilakukan pengukuran kembali terhadap subjek yang sama. Sebaliknya, uji reliabilitas merupakan suatu cara untuk melihat keajegan suatu alat ukur terhadap instrumen pertanyaan.

Uji validitas yang dilakukan terhadap 30 responden dengan 24 pernyataan yang terdiri atas 19 pernyataan pada variabel $X$ dan 5 pernyataan pada variabel $\mathrm{Y}$, setelah dilakukan pengujian didapatkan hasil yang dapat dilihat pada Tabel 2 yang menyatakan bahwa semua variabel adalah valid. Sebaliknya, pengujian terhadap reliabilitas instrumen dengan menggunakan rumus alpha cronbach dapat dilihat pada Tabel 3, yaitu semua variabel $\mathrm{X}$ dan $\mathrm{Y}$ mempunyai nilai alpha di atas 0,6 . Jadi, instrumen tersebut dapat dikatakan reliabel.

\subsection{Deskripsi Hasil Penelitian}

Dari pernyataan pada kuesioner yang telah diajukan kepada responden diperoleh berbagai macam tanggapan terhadap variabel trust in a brand. Berbagai tanggapan dari responden tersebut telah diringkas dan disajikan di bawah ini.

\subsubsection{Brand characteristic.}

Brand characteruistic (karakteristik merek) berkaitan dengan kepercayaan konsumen terhadap suatu merek. Keercayaan di sini menyangkut tentang kinerja merek dapat diramalkan, mempunyai reputasi dan kompetensi merek. Dari distribusi terhadap skor jawaban yang diberikan oleh responden terhadap pertanyaan karakteristik merek dapat dilihat pada Tabel 4.

Variabel brand characteristic (X1) diukur dengan menggunakan dua belas buah pernyataan. Pensekoran dilakukan dengan menggunakan skala Likert dengan interval skor 1 sampai dengan 5. Seluruh skor jawaban yang terkumpul untuk variabel brand characteristic adalah sebanyak 1.368 pernyataan, yang berasal dari 114 responden dengan 12 jumlah pertanyaan, dengan distribusi skor jawaban pada Tabel 4.

Untuk kepentingan penilaian jawaban responden, maka pengelompokan kategori penilaian dilakukan (selanjutnya model ini akan terus digunakan) sebagai berikut. a. Kategori sangat setuju, setuju, dan cukup setuju dikelompokkan ke dalam penilaian setuju.

b. Kategori sangat tidak setuju dan tidak setuju dikelompokkan ke dalam penilaian tidak setuju.

Mengacu pada distribusi skor pada Tabel 4 dapat diketahui bahwa sebanyak 81,94 \% responden setuju dengan kondisi dari dimensi brand characteristic air mineral Aqua dan 18,06 $\%$ responden menyatakan tidak setuju. Ini menunjukkan bahwa dimensi brand characteristic dapat membentuk kepercayaan responden terhadap air mineral Aqua.

\subsubsection{Company Characteristic}

Karakteristik perusahaan yang ada di balik merek akan berpengaruh terhadap loyalitas merek. Karakteristik perusahaan merupakan dasar awal pemahaman konsumen terhadap suatu produk. Karakteristik ini meliputi reputasi suatu perusahaan serta integritas perusahaan di balik merek tersebut.

Dari hasil distribusi terhadap skor jawaban responden terhadap brand characteristic terhadap pertanyaan yang diberikan kepada responden dapat dilihat pada Tabel 5. Variabel company characteristic (X2) diukur dengan menggunakan empat buah pernyataan. Seluruh skor jawaban yang terkumpul untuk variabel company characteristic adalah sebanyak 456 pernyataan, yang berasal dari 114 responden dengan 4 jumlah pertanyaan. Mengacu pada distribusi skor pada Tabel 5 diketahui 41 jawaban $(8.99 \%)$ sangat setuju, 137 jawaban (30.04 \%) setuju, 149 jawaban $(32.68 \%)$ cukup setuju, 111 jawaban $(24.34 \%)$ tidak setuju, dan jawaban yang sangat tidak setuju sebanyak 18 jawaban (3.95\%).

Apabila ditinjau dari jawaban responden, yang sangat setuju, setuju, dan cukup setuju sebanyak 327 atau $71,71 \%$, sedangkan total jawaban responden yang tidak setuju dan sangat tidak setuju sebanyak 129 atau $28.29 \%$. Jadi, dapat dijelaskan bahwa dimensi company characteristic dapat membentuk kepercayaan responden terhadap air mineral Aqua.

\subsubsection{Consumer - Brand Characteristic}

Karakteristik konsumen - merek merupakan totalitas pemikiran dan perasaan individu dengan acuan dirinya sebagai objek sehingga sering kali dalam konteks pemasaran dianalogkan merek sama dengan orang. Konsumen sering kali berinteraksi dengan merek seolah olah merek tersebut adalah manusia sehingga kesamaan antara konsep diri konsumen 
dengan merek dapat membangun kepercayaan terhadap merek.

Distribusi skor jawaban responden terhadap pertanyaan karakteristik konsumen merek dapat dilihat pada Tabel 6.Variabel consumer - brand characteristic (X3) diukur dengan menggunakan tiga buah pernyataan. Seluruh skor jawaban yang terkumpul untuk variabel consumer - brand characteristic adalah sebanyak 342 pernyataan, yang berasal dari 114 responden dengan 3 jumlah pertanyaan. Mengacu pada distribusi skor jawaban pada Tabel 6 diketahui 38 jawaban $(11.11 \%)$ sangat setuju, 87 jawaban $(25.44 \%)$ setuju, 121 jawaban $(35.38$ $\%$ ) cukup setuju, 85 jawaban (24.85\%) tidak setuju, dan jawaban yang sangat tidak setuju sebanyak 11 jawaban (3.22\%).

Apabila ditinjau dari jawaban responden, yang sangat setuju, setuju, dan cukup setuju sebanyak 246 responden atau 71,93\%, sedangkan total jawaban responden yang tidak setuju dan sangat tidak setuju sebanyak 96 atau $28.07 \%$ Ini berarti bahwa dimensi consumer brand characteristic dapat membentuk kepercayaan responden terhadap air mineral Aqua.

\subsubsection{Brand Loyalty}

Loyalitas merek dapat dipandang sebagai komitmen internal dalam diri konsumen untuk membeli dan membeli ulang suatu merek tertentu meskipun ada pengaruh situasional dan usaha pemasaran yang dapat menimbulkan perilaku peralihan. Distribusi skor jawaban responden terhadap pertanyaan loyalitas merek dapat dilihat pada Tabel 7. Variabel brand loyalty (Y) diukur dengan menggunakan lima buah pernyataan. Seluruh skor jawaban yang terkumpul untuk variabel consumer-brand characteristic adalah sebanyak 570 pernyataan, yang berasal dari 114 responden dengan 5 jumlah pertanyaan, dengan distribusi skor jawaban pada Tabel 7.

Mengacu pada distribusi skor pada Tabel 7, 76 jawaban (13.16 \%) sangat setuju, 193 jawaban $(34.21 \%)$ setuju, 169 jawaban (29.82 $\%)$ cukup setuju, 113 jawaban $(19.30 \%)$ tidak setuju, dan jawaban yang sangat tidak setuju sebanyak 19 jawaban $(3.51 \%)$. Apabila ditinjau dari jawaban responden yang sangat setuju, setuju, dan cukup setuju sebanyak 438 responden atau $77,19 \%$, sedangkan total jawaban responden yang tidak setuju dan sangat tidak setuju sebanyak 132 atau $22.81 \%$. Ini menunjukkan bahwa responden loyal terhadap air mineral Aqua.

\subsection{Hasil Pengujian Asumsi Klasik}

\subsubsection{Uji Linearitas}

Uji linearitas dilakukan dengan menggunakan diagram pencar (scatter plot) dengan memberikan tambahan garis regresi.Berdasarkan hasil pengujian yang ada pada lampiran dapat dilihat bahwa garis regresi pada scatter plot semuanya mengarah ke kanan atas. Hal ini membuktikan bahwa adanya linearitas antara variabel brand characteristic, company characteristic, dan consumer brand characteristic dengan brand loyalty.

\subsubsection{Uji Normalitas}

Uji normalitas dimaksudkan untuk mengetahui apakah distribusi sebuah data mengikuti atau mendekati distribusi normal. Berdasarkan hasil uji normalitas serta sesuai dengan grafik output yang ada pada lampiran, deteksi normalitas dapat dilihat dari penyebaran titik-titik pada sumbu diagonal dari grafik. Dalam grafik terlihat data menyebar di sekitar garis diagonal dan mengikuti arah garis diagonal. Dengan demikian, maka model dalam penelitian ini sudah memenuhi uji normalitas.

\subsubsection{Uji Multikolinearitas}

Uji multikolinearitas digunakan untuk mengetahui apakah model regresi ditemukan adanya korelasi antarvariabel bebas yang digunakan dalam penelitian. Untuk mendeteksi gejala adanya multikolinearitas dapat dilakukan dengan menggunakan besarnya nilai VIF (Variance Influence Faktor) dan angka tolerance. Pedoman suatu model agar terbebas dari multikolineritas adalah apabila nilai VIF-nya lebih kecil daripada 10.

Dalam analisis ini didapat nilai Variance Influence Faktor (VIF) seperti terlihat dalam Tabel 8. Dari hasil analisis, didapat ketiga variabel bebas dalam penelitian nilai VIF-nya di bawah 10. Ini berarti bahwa tidak terjadi multikolinearitas antara variabel bebas tersebut.

\subsubsection{Heterokedastisitas}

Hasil uji heterokedastisitas menunjukkan bahwa dalam model tidak terjadi ketidaksamaan yang artinya tidak terjadi heterokedastisitas. Untuk mendeteksi heterokedasitas dapat dilakukan dengan meregresikan nilai residual absolut (E-abs) variabel terikat terhadap semua variabel bebas. Model regresi yang baik adalah apabila tidak terjadi heterokedastisitas. Menurut Imam Gozali (2002), suatu regresi dikatakan tidak heteros jika nilai Sig dari t hitung $>0.05$. Dari hasil perhitungan dengan SPSS didapat korelasi Range Spearmans pada Tabel 9 bahwa tingkat signifikan hasil korelasi untuk tiap-tiap 
variabel bebas $>5 \%$. Ini berarti bahwa dari persamaan regresi yang digunakan tidak terjadi heterokedastisitas atau dengan kata lain terjadi homokedastisitas.

\subsubsection{Uji Autokorelasi}

Ada tidaknya autokorelasi dalam penelitian ini dideteksi dengan menggunakan uji Durbin - Watson. Ukuran yang digunakan untuk menyatakan ada tidaknya autokorelasi, yaitu apabila nilai statistik Durbin - Watson mendekati 2, maka dapat dinyatakan bahwa data pengamatan di antara variabel bebas tersebut tidak memiliki autokorelasi.

Berdasarkan hasil analisis pada lampiran dapat diketahui bahwa nilai Durbin - Watson sebesar 2.025. Nilai tersebut dapat dinyatakan mendekati nilai 2. Jadi, disimpulkan bahwa tidak terjadi autokorelasi di antara variabel bebas dalam penelitian.

\subsection{Analisis Regresi Berganda \\ 3.6.1 Analisis Regresi Variabel Trust in a Brand terhadap Brand Loyalty Secara Bersama- sama}

Pengujian hipotesis penelitian ini dilakukan dengan menggunakan model matematis analisis regresi linear berganda. Sesuai dengan hasil analisis pada Tabel 10, secara matematis model tersebut dapat diformulasikan sebagai berikut :

$$
\mathrm{Y}=-0.660+0.289 \mathrm{X} 1+0.243 \mathrm{X} 2+0.203 \mathrm{X} 3
$$

Keterangan :

$$
\begin{array}{ll}
\mathrm{Y}_{2} & =\text { Brand Loyalty } \\
\mathrm{X}_{1} & =\text { Brand characteristic. } \\
\mathrm{X}_{2} & =\text { Company characteristic } \\
\mathrm{X}_{3} & =\text { Consumer-brand characteristic. }
\end{array}
$$

Berdasarkan hasil analisis dapat diketahui bahwa secara bersama-sama pengaruh variable trust in a brand terhadap brand loyalty adalah sebesar 94,2 \%, sedangkan sisanya sebesar 5,8\% brand loyalty dipengaruhi oleh variabel-variabel lain selain trust in a brand.

a. Konstanta sebesar -0,660 menyatakan bahwa jika tidak ada brand characteristic, company characteristic, dan consumer - brand characteristic (X1, X2, dan X3 adalah 0), maka tidak ada brand loyalty.

b. Koefisien regresi brand characteristic (X1) sebesar 0,289, company characteristic (X2) sebesar 0,243, dan consumer - brand characteristic (X3) sebesar 0,203 semuanya bertanda positif. Artinya, terjadi pengaruh yang positif/searah antara variabel bebas dengan variabel terikat.

\subsubsection{Analisis Regresi Trust in a Brand terhadap Brand Loyalty secara Parsial}

Pengaruh variabel trust in a brand terhadap brand loyalty secara parsial dapat dilihat pada Tabel 11. Pada tabel dapat dilihat bahwa variabel trust In a brand yang meliputi brand characteristic, company characteristic, dan consumer brand characteristic secara parsial berpengaruh signifikan terhadap brand loyalty.

Secara partial brand characteristic berpengaruh signifikan terhadap brand loyalty yaitu dengan koefisien beta sebesar 0,668 dan tingkat signifikan 0,000. Company characteristic secara signifikan berpengaruh terhadap brand loyalty dengan koefisien beta sebesar 0,224 dan tingkat signifikan 0,000, sedangkan consumer brand characteristic secara signifikan berpengaruh terhadap brand loyalty dengan koefisien beta sebesar 0,165 dan tingkat signifikan sebesar 0,000 .

\section{SIMPULAN DAN SARAN 4.1 Simpulan}

Berdasarkan hasil penelitian setelah diolah dengan menggunakan alat analisis yang digunakan dapat disimpulkan sebagai berikut :

(1) Secara bersama-sama variabel trust in a brand yang meliputi brand characteristic $(X 1)$, company characteristic $(X 2)$, dan consumer-brand characteristic (X3) mempengaruhi brand loyalty. Besarnya pengaruh variabel trust in a brand tersebut adalah 0.942 dengan tingkat signifikan 0.000 .

(2) Secara parsial variabel trust in a brand yang meliputi brand characteristic, company characteristic, dan consumer brand characteristic berpengaruh signifikan terhadap brand loyalty. Brand characteristic (X1) secara signifikan berpengaruh terhadap brand loyalty dengan koefisien beta sebesar 0.668 dengan tingkat signifikan 0.000 , company characteristic (X2) cukup signifikan berpengaruh terhadap brand loyalty dengan koefisien beta sebesar 0.224 dan tingkat signifikan 0.000, dan consumer - brand characteristic (X3) cukup signifikan berpengaruh terhadap brand loyalty dengan koefisien beta sebesar 0.165 dan tingkat signifikan 0.000. Dari ketiga variabel trust in a brand tersebut brand characteristic yang berpengaruh dominan terhadap brand loyalty. 


\subsection{Saran - Saran}

PT Tirta Investama khususnya divisi distribusi sebaiknya senantiasa mempertahankan dan meningkatkan brand characteristic. Hal ini disebabkan oleh variabel brand characteristic merupakan variabel yang paling kuat dan dominan berpengaruh terhadap brand loyalty dan variabel tersebut dapat dikendalikan secara langsung oleh perusahaan. Upaya peningkatan kepercayaan konsumen terhadap brand characteristic tersebut dapat dilakukan melalui peningkatan intensitas kegiatan kegiatan yang berhubungan dengan masyarakat sehingga citra dan kredibilitas perusahaan dapat terus terjaga.

\section{DAFTAR PUSTAKA}

Aaker A David. 1997. Ekuaitas Merek. Edisi Indonesia. Jakarta : Mitra Utama.

Blackstone, Elena Delgado and Jose Lius Manuera - Aleman. 2001. "Brand Trust In Context of Consumer Loyalty". European Journal of Marketing. Vol 35 (11/12).

Darmmesta, Basu Swasta. 1999. "Loyalitas Pelanggan.Sebuah Kajian Konseptual Sebagai Panduan bagi Peneliti". Jurnal Ekonomi dan Bisnis Indonesia. Vol 14/3: 73-88.

Gujarati, Damodar N. 1995. Basic Econometric. Third Edition. New York: McGraw - Hill Book Company.

Irawan, Handi. 2003. Indonesian Customer Satisfaction. Jakarta: PT. Alex Media Computindo.

Kotler Philip. 2000. Manajemen Pemasaran. Edisi Milenium. Jakarta: Prenhallindo.

Lau, Geok Then and Sook Han Lee. 1999. "Consumers Trust in a Brand and the Link to Brand Loyalty". Journal of Market Focused Management.

Mowen. John C / Michael Minor. 2001. Perilaku Konsumen. Jakarta: Penerbit Erlangga.

Rangkuti, Fredddy. 2002 The Power of Brands, Teknik Mengelola Brand Equity dan Strategi Pengembangan Merek. Jakarta: Gramedia Pustaka.

Sakaran Uma. 1992. Research Methods for Business, A Skill Building Approach. Second Edition. New York: John Willey \& Sons, Inc.

Sudjana. 1996. Teknik Analisis Regresi dan Korelasi bagi Para Peneliti. $\quad$ Bandung: Tarsito.

Sugiyono. 2003. Metode Penelitian Bisnis. Bandung : CV Alfabeta.

Tjiptono, Fandi. 1997. Strategi Pemasaran. Yogyakarta: Penerbit Andi. 